\title{
Introduction To U.S. Free Trade Agreements
}

\author{
David A. Gantz* \\ University of Arizona, USA
}

\begin{abstract}
This introduction explores the historical changes in the trade policies of the United States (U.S.), namely, the shift from the support of multilateral rules to the embracement of regional trade agreements and provides an overview of the political and economic considerations behind the conclusion of the major U.S. free trade agreements.
\end{abstract}

\section{CONTENTS}

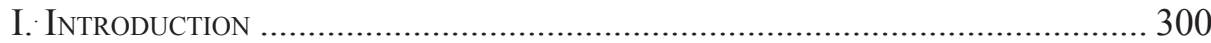

II. Free Trade Agreements in the General Agreement on Tariffs and Trade...300

III. The United States’ Embrace of Free Trade Agreements...................... 302

IV. The U.S.-Israel Free Trade Agreement ............................................ 306

V. Canada-United States Free Trade Agreement..................................... 307

VI. North American Free Trade Agreement ............................................ 308

VII. The Jordan and other Middle Eastern Free Trade Agreements........ 308

ViII. The Bush Era Free Trade Agreements in Latin America and Asia ... 310

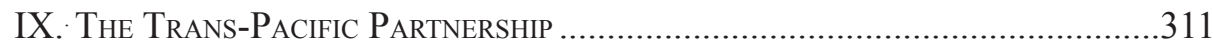

X. Transatlantic Trade and Investment Partnership? ............................. 313

* Samuel M. Fegtly Professor of Law and Director Emeritus, International Economic Law and Policy Program, University of Arizona, A.B. (1961), Harvard College, J.D. (1967), J.S.M. (1970), Stanford Law School; He can be reached at dagantz@email.arizona.edu. 


\section{INTRODUCTION}

This article explores the historical changes in trade policies that brought the United States government from a staunch supporter of trade liberalization under the General Agreement on Tariffs and Trade (GATT) (and generally an opponent of liberalization through regional agreements ${ }^{1}$ ), to an enthusiastic negotiator of regional trade agreements, all over a period of about 35 years. ${ }^{2}$ Since 1985, the United States (U.S.) has concluded free trade agreements (FTAs) with a total of nearly thirty nations, including most recently the Trans-Pacific Partnership (TPP). ${ }^{3}$ Slowly progressing negotiations are underway with the European Union (EU), which if and when successful would add another twenty-eight countries as FTA partners. ${ }^{4}$ U.S. policy has also shifted from seeing free trade agreements as a second best approach to trade liberalization to one where, after the failure of the WTO's Doha Development Round, the focus is decidedly on the regional agreements, most significantly the TPP and the Transatlantic Trade and Investment Partnership (TTIP). In addition to the trade liberalization that has taken place in free trade agreements, the United States Government views the most recent free trade agreements as a positive force. If the process is successful, it could eventually bring broader trade liberalization from the regional to the global level, and assure that the United States has a major role in setting the rules for international trade in the future.

\section{Free Trade Agreements in the General Agreement ON TARIFFS AND TRADE}

A GATT without an exception for customs unions would not have been consistent with post World War II foreign policy in Europe. In addition to the U.S. Marshall Plan and the efforts of the World Bank, both designed to support the economic and industrial reconstruction of Europe, the United States strongly supported the economic unification of Western Europe as an antidote to a possible World War III. The Marshall Plan aid was channeled primarily through a common European program, rather than on a country-by-country basis. ${ }^{5}$ Further, the United States opposed French efforts to prevent Germany from again becoming an industrial

1 See Canada-US Automotive Products Agreement, Jan. 1965, Historica Canada, available at http://www.thecanadianencyclopedia.ca/en/article/canada-us-automotive-products-agreement.

2 Much of this history is discussed in detail in David A. Gantz, Regional Trade Agreements: Law, Policy and Practice (2009) [hereinafter Gantz, RTAs].

3 Trans-pacific Partnership Agreement [Australia, Brunei, Canada, Chile, Japan, Korea, Malaysia, Mexico, Peru, Singapore, United States and Vietnam], Feb. 4, 2016, available at https://ustr.gov/tpp (last visited Mar. 26, 2016).

4 See EU Commission, The Transatlantic Trade Investment Partnership, available at http://ec.europa. eu/trade/policy/in-focus/ttip (last visited Mar. 26, 2016). Should the U.K. withdraw from the EU, as seems highly likely as of October 2016, the number would of course be reduced to 27 .

5 See Robert Wilde, The Marshall Plan, available at http://europeanhistory.about.com/od/ coldwar/p/prmarshallplan.htm (last visited Jan. 15, 2016). 
power. ${ }^{6}$ European economic union was not of course a U.S. idea. Churchill, among others, suggested in 1946 that a (customs) union of France and Germany could be the initial step in a broader union of European nations. ${ }^{7}$

Still, possible future European economic integration was not the only or perhaps even the most significant driving force. Professor John Jackson observed that some countries treated regional agreements as exceptions to Most-FavoredNation (MFN) treatment well before the GATT was drafted. The United States sought a "dismantling" of trade preferences in the 1946-47 GATT negotiations and in the ill-fated International Trade Organization (ITO) Charter, where particular concerns had arisen with respect to the preferences extended to members of the British Commonwealth. ${ }^{8}$ According to Jackson, even the United States "recognized the legitimacy of an exception for customs unions," and was willing to permit such arrangements "without opening the door to the introduction of all preferential systems under the guise of a customs union." Professor Petros Mavroidis further suggests that some negotiators at the conference wanted to regulate "frontier traffic" (trade between adjacent countries) while others saw the exception as a tool to legitimate preexisting arrangements or to further economic development, or even as a kind of insurance policy in the event that the new multilateral system were to break down. ${ }^{10}$ Although the United States had pressed for a requirement of immediate adoption of the customs union, other delegations urged that there be a transition or interim period. This latter view ultimately prevailed in Article XXIV. It was at the Havana Conference, where the International Trade Organization agreement was drafted, that the idea of a free trade area was added to the exception for customs unions.

In the course of the drafting of the General Agreement on Tariffs and Trade in 1946 and 1947, the United States thus accepted the necessity of including in the GATT an exception to the fundamental non-discrimination principle of most favored nation treatment, with the U.S. delegate (probably Harry Hawkins) instrumental in proposing the draft of what eventually became Article XXIV. ${ }^{11}$ The decision was made to include in Article XXIV language that would permit the deviation from MFN treatment only under what were believed to be narrow circumstances. The most important of these included requirements that the free trade area or customs union would achieve coverage of substantially all intra-regional trade within a reasonable period of time, and would preclude the Parties from increasing tariffs and non-tariff barriers for goods imported from outside the region. ${ }^{12}$

6 See Damian Chalmers, 1 European Union Law: Law and EU Government 8-9 (1998) (relating U.S. involvement in shaping an economically integrated Europe in the 1940s). Id. at 9 .

See Jackson, at 576-580 (discussing the drafting of Article XXIV).

Id. at 577.

Petros C. Mavroidis, I The Regulation of International Trade: Gatt 293 (2016).

Id. at 292.

GATT, art. $\operatorname{XXIV(5(b),~XXIV(8)(b).~}$ 


\section{The United States’ Embrace of Free Trade Agreements}

The United States came relatively late to the conclusion that regional trade agreements ${ }^{13}$ were a desirable and even necessary element of a comprehensive trade liberalization policy. Throughout multiple GATT negotiating "rounds" designed to achieve global tariff and non-tariff barrier reductions, at least through the Tokyo Round (1973-79), the United States remained a strong supporter of the multilateral trading system. The shift toward Regional Trade Agreements (RTAs) began only in the mid-1980s.

This change can be attributed primarily to two factors. First, the European Economic Community (now European Union), which had made only relatively slow progress toward deeper economic integration in the 1970s and early 1980s, finally took the necessary steps toward a full common market with the Single Market Initiative, adopted after much discussion and debate in 1986, for implementation in 1992. The establishment of what eventually would be a true European Union had a significant demonstration effect elsewhere in the world. ${ }^{14}$ The United States, although a long-term supporter of European integration, could not fail to grasp the importance of Europe's enhanced access to relatively low-wage production with the accession of Ireland (1973), Greece (1979) and Spain and Portugal (1986) ${ }^{15}$ and the implications for Europe's competitiveness with the Western Hemisphere and with Asia.

These considerations were also reinforced by U.S. frustration from 1982-1985 in efforts to achieve further global trade liberalization through the GATT in Geneva, primarily because of a lack of support for a new GATT negotiating round from the (internally preoccupied) Europeans. U.S. Trade Representative and former Senator William Brock and his allies in the U.S. Government decided to respond to this rebuff by championing regional initiatives with the Israel and then Canada FTAs. The Reagan Administration also enacted unilateral tariff preferences for nearby developing countries in Central America and the Caribbean through the Caribbean Basin Initiative. ${ }^{16}$ The logic then as today with the WTO's failed Doha Round was that if the then-preferred global freer trade initiatives could not move forward, regional trade arrangements could provide a viable alternative. ${ }^{17}$

The strategy worked in the mid-1980s. Concerns about the United States' new bilateral course, which could have been expanded beyond Israel and

13 In this discussion the term "regional trade agreements" is used as on the WTO website to refer to those agreements that are not multilateral in natures such as those concluded under the auspices of the GATT/WTO in Geneva. (See WTO.org, last visited Jan. 8, 2016). This includes the true RTAs such as NAFTA, where the Parties share common borders, as with NAFTA, and those that cross several regions, such as the U.S. FTA with Singapore and Australia, and the Trans-Pacific Partnership. See Robert V. Fioentino et al., The Changing Landscape of Regional Trade Agreements: 2006 Update, WTO Discussion Paper no. 12 (2006), available at https:/www.wto.org/english/res_e/ discussion_papers12a_e.pdf.

14 Jeffrey A. Frankel, Regional Trading Blocs in the World Economic System 4-5 (Inst. for Int'1 Economics, 1997).

15 Paolo Mengozzi, European Community Law 3 ( 1992).

16 Id. 5-6. These developments are also discussed in William A. Lovett, Alfred E. EcKes, JR. \& Richard Brinkman, U.S. Trade Policy: History, Theory and the WTO 94-95 (M.E. Sharpe, 1999).

17 See also infra, part III on the U.S.-Israel Free Trade Agreement. 
Canada, likely prompted the Europeans to agree a new round of multilateral trade negotiations (in 1986). ${ }^{18}$ However, the new policy accepting the desirability of regional trade agreements ultimately continued well beyond the United StatesCanada Free Trade Agreement (CFTA) ${ }^{19}$ to the North American Free Trade Agreement (NAFTA), ${ }^{20}$ which was negotiated and concluded by the first Bush Administration in 1991-92 but ultimately steered through Congress by the Clinton Administration in 1993. It is difficult to know whether in the absence for several years of progress in concluding the Uruguay Round NAFTA would have gone forward, even after three years of more or less satisfactory operation of the CFTA. Still, the Uruguay Round GATT negotiations were largely stalled from 1991-1992 primarily because of disagreements between the United States and the European Communities over reduction of agricultural subsidies, along with wider differences over services, market access, anti-dumping and a new institution. ${ }^{21}$ This two-year delay provided the United States, Canada and Mexico with a convenient window to conclude the NAFTA negotiations. ${ }^{22}$ By the time the Uruguay Round impasse over agriculture was resolved through the so-called Blair House Accord in November 1992, ${ }^{23}$ paving the way for concluding the signing of the Uruguay Round Agreements in April 1994, NAFTA was well on its way to entering into force.

This is not to suggest that with the success of the NAFTA negotiations the U.S. Government embarked on a continuing process of negotiating additional free trade agreements. It was widely believed by those in the Clinton Administration and many observers that NAFTA could and would be expanded to include other Western Hemisphere states (beginning with Chile). However, this did not happen, in large part because the Republican Congress refused to renew President Clinton's "fast track" negotiating authority once it expired in mid-1994. ${ }^{24}$ (In fairness to the Republicans in Congress, renewal would have been a mixed blessing for the Clinton Administration, since several of the President's core constituencies, labor and environmental groups, generally opposed further trade liberalization. $)^{25}$

The highly ambitious Clinton-sponsored negotiations for a Free Trade Area of the Americas (FTAA) beginning in December 1994 achieved little progress during

18 See Lovett et al., supra note 16, at 100.

19 United States-Canada Free Trade Agreement, Dec. 1997-Jan. 1998 [U.S.-Can.], 27 I.L.M. 281 (1998), also available at http:/www.international.gc.ca/trade-agreementsaccords-commerciaux/assets/pdfs/cusfta-e.pdf (last visited Jan. 13, 2016).

20 North American Free Trade Agreement, Dec. 17, 1992, U.S.-Mexico-Canada, 32 I.L.M. 289 (1993), also available at https://www.nafta-sec-alena.org/Home/Legal-Texts/NorthAmerican-Free-Trade-Agreement.

21 See Understanding the WTO: The Uruguay Round, World Trade Organization available at https://www.wto.org/english/thewto_e/whatis_e/tif_e/fact5_e.htm.

22 The negotiations began in February 1991, with the agreement signed in December 1992. See North American Free Trade Agreement, Chronology of Events, NAFTANow.org, available at http://www.naftanow.org/about/default_en.asp.

23 See Understanding the WTO: The Uruguay Round, supra note 21 (noting that "The US and EU settled most of their differences on agriculture in a deal known informally as the 'Blair House accord.'”).

24 See Gantz, RTAs, supra note 2, ch. 5 (political factors) \& ch. 12 (MERCOSUR)

25 For a discussion of the failed efforts to include Chile in NAFTA, see RaLPH Folsom, Michael Gordon \& David Gantz, NAFtA and Free Trade in the Americas: A ProblemOriented Coursebook 772-796 ( $2^{\mathrm{d}}$ ed. 2005$)$. 
the remaining years of the Clinton Administration, and encountered no greater success under the George W. Bush Administration, even after fast track was renewed as Trade Promotion Authority in 2002. ${ }^{26}$ The reasons for this failure are many. Still, the most significant was the inability of the United States and Brazil to agree on a way forward. The United States was insisting on better access for U.S. goods to the Brazilian market but unwilling to address several long-standing anti-dumping orders affecting, inter alia, steel and orange juice, or to agree in a regional trade agreement to significantly reduce or eliminate agricultural subsidies. ${ }^{27}$ In retrospect, one wonders whether even had the economic disagreements been resolved Brazil would have welcomed a broad free trade agreement that inevitably would have been dominated by the superior economic and political power of the United States. The alternative course of action chosen by Brazil in the first decade of the twentyfirst century, to establish broader FTA relationships with all of the South American nations except for the Guyanas, probably made better political sense for Brazil. ${ }^{28}$

The Clinton Administration, even without fast track, did manage to achieve some significant RTA initiatives, including the signing of a free trade agreement with Jordan and a bilateral trade agreement with Vietnam, both in 1999. ${ }^{29}$ Several last-minute Clinton administration FTA initiatives, with Singapore and Chile, were enthusiastically and successfully pursued by the George W. Bush Administration, which embraced the concept of regional trade agreements more fully than any previous U.S. administration.

Between 1999 and 2007, the United States concluded free trade agreements with Jordan (JFTA), ${ }^{30}$ Singapore, ${ }^{31}$ Chile $^{32}$, Central America and the Dominican Republic (CAFTA-DR), ${ }^{33}$ Morocco, ${ }^{34}$ Peru, ${ }^{35}$ Australia, ${ }^{36}$ Colombia, ${ }^{37}$ Oman, ${ }^{38}$

26 See Free Trade AREA of the Americas, available at http://www.ftaa-alca.org/alca e.asp (last visited Jan. 19, 2016) (providing history, negotiating texts and other information on the FTAA).

27 See Kevin C. Kennedy, The FTAA Negotiations: A Melodrama in Five Acts, 1 Loyola INT'L L. Rev. 121 (2004).

28 See Gantz, RTAs, supra note 2, RTAs, ch. 12 (MERCOSUR).

29 For Vietnam, a variant of fast track applicable to non-market economies remained in force. See Trade Act of 1974, secs. 151, 404, 405, 407, Publ. L. 93-618), 19 U.S.C. $\S \S 2191$ et seq.

30 Agreement Between the United States of America and the Hashemite Kingdom of Jordan on the Establishment of a Free Trade Area, Oct. 24, 2000, available at https:// ustr.gov/trade-agreements/free-trade-agreements/jordan-fta/final-text .

31 United States-Singapore Free Trade Agreement, May 6, 2003, U.S.-Sing., available at https://ustr.gov/trade-agreements/free-trade-agreements/singapore-fta/final-text.

32 United States-Chile Free Trade Agreement, Jun. 6, 2003, U.S.-Chile, available at https:// ustr.gov/trade-agreements/free-trade-agreements/chile-fta/final-text.

33 Central American-Dominican Republic-United States Free Trade Agreement, Aug. 5, 2004, U.S.-Dom. Rep.-Guat.-El Salvador- Hond.-Nicaragua, available at https://ustr. gov/trade-agreements/free-trade-agreements/cafta-dr-dominican-republic-centralamerica-fta/final-text.

34 United States-Morocco Free Trade Agreement, Jun. 15, 2004, available at https://ustr. gov/trade-agreements/free-trade-agreements/morocco-fta/final-text.

35 United States-Peru Trade Promotion Agreement, Apr. 12, 2006, available at https://ustr. gov/trade-agreements/free-trade-agreements/peru-tpa/final-text.

36 United States-Australia Free Trade Agreement, May 18, 2004, available at https://ustr. gov/trade-agreements/free-trade-agreements/australian-fta/final-text.

37 United States-Colombia Trade Promotion Agreement, Nov. 22, 2006, available at https://ustr.gov/trade-agreements/free-trade-agreements/colombia-fta/final-text.

38 United States-Oman Free Trade Agreement, Jan. 18, 2006, available at https://ustr.gov/ trade-agreements/free-trade-agreements/oman-fta/final-text. 
Bahrain, ${ }^{39}$ Panama ${ }^{40}$ and South Korea. ${ }^{41}$ The Congressional approval and entry into force of those with Panama, Colombia and South Korea were significantly delayed by various factors, mostly U.S. labor union and civil society concerns with the lack of security provided by then then-Colombian government to labor union officials, who were being murdered in significant numbers. All three of these agreements were finally submitted to Congress by the Obama Administration in September 2011, and approved shortly thereafter. ${ }^{42}$ Negotiations also took place at various levels of intensity with other countries, including Thailand, Malaysia, the United Arab Emirates and South Africa, all without success. ${ }^{43}$

The ultimately successful multi-year initiative of the Obama Administration to conclude the TPP negotiations, discussed by Tania Voon and Elisabeth Sheargold in this issue, is the latest and most significant free trade agreement concluded by the United States or any other nation since NAFTA more than twenty years earlier. The twelve TPP Parties represent nearly $40 \%$ of total world trade in goods, amounting to about $\$ 1.8$ trillion worth in $2012 .{ }^{44}$ The other major, equally significant economically negotiation in which the United States is a party, the TTIP, discussed by Christian Pitschas in this issue, is moving at a much slower pace and seems unlikely to be concluded before 2018 if at all. Predictions as to the extent to which the United States will continue to pursue regional trade agreements in the coming years are virtually impossible, as the answer depends on who is elected president in November 2016 and the extent to which that administration, and the members of Congress and the Senate, are supporters of further trade liberalization. If by the end of 2018 the TPP has been approved by Congress and entered into force, and the TTIP negotiations have been concluded, this would be strong evidence that the US shift in focus from multilateral trade agreements to regional trade agreements

39 Agreement between the Government of the United States and the Government of the Kingdom of Bahrain on the Establishment of a Free Trade Agreement, Sep. 14, 2004, available at https://ustr.gov/trade-agreements/free-trade-agreements/bahrain-fta/finaltext.

40 Panama Trade Promotion Agreement, June 28, 2007, available at https://ustr.gov/tradeagreements/free-trade-agreements/panama-tpa/final-text.

41 United States-Korea Free Trade Agreement, Jun. 30, 2007, available at https://ustr.gov/ trade-agreements/free-trade-agreements/korus-fta/final-text.

42 See Congress Approves 3 Free Trade Agreements, Oct. 11, 2011, CBSNews.com, available at http://www.cbsnews.com/news/congress-approves-3-free-trade-agreements.

43 For example, President Bush announced on October 20, 2003 his intention to negotiate a free trade agreement with Thailand. See White House, Fact Sheet on Free Trade with Thailand, available at http://georgewbush-whitehouse.archives.gov/news/releases/2003/ 10/20031020-27.html (last visited Jan. 19, 2016). Prime Minister Thaksin Shinawatra was deposed in a coup in 2006 and the negotiations were never concluded. Negotiations also took place for several years with the Union of South Africa, but ultimately failed due to South Africa's unwillingness to include commitments on intellectual property, services and investment. Ultimately, the United States and South Africa settled for a "Trade, Investment and Development Cooperative Agreement". See U.S. Department of States, U.S. Relations with South Africa, Oct. 7, 2015, available at http://www.state. gov/r/pa/ei/bgn/2898.htm; Gantz, RTAs, supra note 2, at 450-51. Malaysia is a Party to the TPP.

44 See USTR Fact Sheet: Economic Benefits of Trans-Pacific Partnership, Dec. 10, 2013, available at http://iipdigital.usembassy.gov/st/english/texttrans/2013/12/ 20131211288766.html\#axzz3xjv4JdaC. 
is complete even if occasional multilateral or plurilateral agreements are concluded periodically under WTO auspices in Geneva. The alternative could instead be at least a temporary abandonment of major trade agreements by a new president, whether regional or global.

\section{The U.S.-Israel Free Trade Agreement}

The Israel agreement was the first U.S. foray into free trade agreements. It was concluded more for foreign policy and national security reasons than economic benefits per se, although some U.S. exporters were concerned that because of a 1975 FTA between the European Union and Israel ${ }^{45}$ some American trade interests would be disadvantaged because of the reduction or elimination of most duties on two-way non-agricultural trade ${ }^{46}$ Israel first proposed a free trade agreement with the United States in 1981 and Congress quickly authorized the negotiation and conclusion of the agreement under the United States" "fast track" trade negotiating authority. ${ }^{47}$ Unlike future trade agreements, the IFTA apparently received the unanimous treatment of Congress. The decision to conclude a free trade agreement was undoubtedly influenced by the "strong political and military ties" that existed between Israel and the United States since Israel's creation as an independent state in $1948 .^{48}$ Both the United States and Israel saw the agreement as a means of strengthening Israel's always vulnerable position in the Middle East against Arab and Soviet opposition, and supporting the only democratic government in the region. ${ }^{49}$

On the economic side, concerns were raised that Israel might be hurt if the U.S. Generalized System of [unilateral tariff] preferences were not renewed by the Congress, or if the Arab boycott of Israel expanded. The negotiation of an agreement with Israel also appeared to provide a relatively low risk opportunity for the United States to experiment with its first free trade agreement. ${ }^{50}$ Other factors may have been less important, including the belief that it would be politically beneficial for the United States to be negotiating with what at the time was a developing country, given the pressures of many developing nations to establish a "new economic order" that was considered potentially harmful to U.S. interests. ${ }^{51}$

This first U.S. FTA was far less ambitious that the Canada-United States Free Trade Agreement a few years later and less comprehensive still than NAFTA, as noted below. The IFTA contained only twenty-three articles and four annexes. It did

45 May 20, 1975 [Israel-EEC], 18 O.J. Eur. Comm. (No. L. 136) 1 (1975).

46 Ira Nickelsberg, The Ability to Use Israel's Preferential Trade Status with both the United States and the European Community to Overcome Potential Trade Barriers, 24 Geo. Wash. J. InT'L L. \& ECON. 371, 372 (1990).

47 Trade and Tariff Act of 19784, $\S 4401-406,19$ U.S.C.A. $\$ 2112$ \& Note (West 1985).

48 Yair Baranes, The Motivations and the Models: A Comparison of the Israel-U.S. Free Trade Agreement and the North American Free Trade Agreement, 17 N.Y.L. ScH. J. InT'L \& Comp. L. 145, 146 (1997).

49 See Gantz, Regional Trade Agreements, supra note 2, at 209.

50 Id.

51 Roberto Aponte Toro, The U.S.-Israel FTA: The First Step in U.S.A. New Offensive for "Freer Trade," 63 Rev. Jur. U.P.R. 89, 100 (1994). 
not cover most agricultural trade or investment but it did apply to some services and intellectual property, taking it well beyond the 1947 GATT. ${ }^{52}$

\section{Canada-United States Free Trade Agreement}

In contrast to the IFTA, the CFTA was deep and comprehensive for the time, when many other free trade agreements at the same time or later covered only trade in goods. ${ }^{53}$ At the outset, it is notable that this CFTA was the fourth free trade agreement negotiated between the United States and Canada between the 1850s and 1988, the first long before either nation had any serious interest in regional trade arrangements except with each other. ${ }^{54}$ This history suggests that one of CFTA's most remarkable features was that it was ratified by both Parties and entered into force rather than being abandoned by one or the other government before it could be ratified. Free trade was actually implemented to some degree while Canada was still under the political control of Great Britain in 1855, but the United States Congress voted in 1866 to cancel the treaty. ${ }^{55}$ (Perhaps the frustration with the slow pace of the approval of new GATT negotiations in the mid-1980s affected Canada as well as the United States with regard to its embrace of CFTA.)

One of the more significant antecedents to the CFTA was the 1956 Automotive Products Agreement, which established freer trade (subject to many complex obligations and restrictions for manufacturers) for Canada and the United States to facilitate the integration of the U.S. and Canadian auto and auto parts market, as noted earlier. ${ }^{56}$ Since the Agreement did not meet the requirements of GATT, Article XXIV, a GATT waiver was sought and received (by the United States but not by Canada). ${ }^{57}$

The CFTA was broader than the IFTA. CFTA covered in addition to trade in manufactured goods (where all tariffs were to be eliminated in no more than ten years) many agricultural goods, limited coverage of immigration, services (including financial services), intellectual property and investment protection (although not investor-state dispute settlement-ISDS), along with state-to-state dispute settlement and a special mechanism for review of unfair trade disputes. ${ }^{58}$ The twenty chapters

See also Aponte, supra note 51, at 101.

53 See Argentina-Chile Free Trade Agreement, Aug. 2, 1991 (covering only trade in goods and excluding most agriculture, services and intellectual property, in only ten substantive

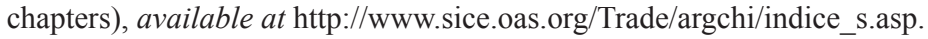

54 For a discussion of the CFTA and its antecedents, see RalPh Folsom, Michael Gordon $\&$ David Gantz, NAFTA and Free Trade in the Americas 10-12, $15-19$ ( ${ }^{\mathrm{d}}$ ed. 2005)

55 See The Reciprocity Treaty of 1854, Historical, Peace and Conflict, available at http:// www.histori.ca/peace/page.do?pageID=345.

56 See Canada-US Automotive Products Agreement, Jan. 1965, Historica Canada, available at $\mathrm{http} / /$ www.thecanadianencyclopedia.ca/en/article/canada-us-automotive-products-agreement.

57 See Jacqueline D. Krikorian, Canada and the WTO: Multilateral, Governance, Public Policy Making and the WTO Auto Pact Case, Case Study no. 9, available at https:// www.wto.org/english/res_e/booksp_e/casestudies_e/case9_e.htm.

58 Canada-United States Free Trade Agreement, Jan. 2, 1998, available at http://www. international.gc.ca/trade-agreements-accords-commerciaux/assets/pdfs/cusfta-e.pdf. 
(rather than articles) represented a far more extensive regional trade agreement than any other negotiated beforehand save for the treaties establishing the European Communities.

\section{North American Free Trade Agreement}

NAFTA is important for any number of reasons, including the then enormous scope of trilateral trade and the expanded coverage over CFTA concluded less than five years earlier. NAFTA went much further, adding ISDS, government procurement, comprehensive intellectual property, government procurement, a wide range of cross-border services, protection of energy trade and telecommunications in the text of the agreement, ${ }^{59}$ and side agreements addressing labor and environmental issues, unique subjects for regional trade agreements at the time, signed simultaneously. ${ }^{60}$

\section{The JoRdAn AND OTHER MiddLe EASTERN Free Trade AgreEments}

The Clinton Administration's single successful new FTA negotiation was a free trade agreement with Jordan, the first at the time with an Arab nation and the first U.S.-initiated agreement to follow the conclusion of the WTO's Uruguay Round. As the first post-NAFTA agreement, the JFTA was also the first to include enforceable environmental and environment provisions in the body of the agreement and the first to address e-commerce issues. ${ }^{61}$ The JFTA consists of a preamble, nineteen articles, three annexes and a variety of joint statements, memoranda of understanding and various side letters. By comparison with NAFTA, and with subsequent U.S. FTAs such as those with Chile, Singapore and CAFTA-DR, the JFTA is a compact package. This widely differing approach, while similar to that of the JFTA, presumably reflected the preferences of the Clinton Administration for a much less comprehensive free trade agreement.

JFTA also remains the only U.S. FTA that was concluded in the absence of "fast-track" provisions, ${ }^{62}$ in the final months (October 2000) of the Clinton Administration. The political complexities surrounding the negotiation and U.S. implementation of the JFTA were significant. The JFTA was linked to the Middle East peace negotiations taking place simultaneously, a major foreign policy initiative of the Clinton Administration's final year. The approval of the JFTA by

\footnotetext{
$59 \quad$ NAFTA, supra note 20, passim.

60 North American Agreement on Labor Consultation, Dec. 15, 1992, available at http://www.naalc.org/naalc/naalc-full-text.htm; North American Agreement on Environmental Cooperation, Dec. 15, 1992, available at http://www.cec.org/Page. asp?PageID=1226\&SiteNodeID $=567$.

61 JFTA, supra note 30 , arts. 5, 6, 7, respectively.

62 Trade Act of 1974, as amended, 19 U.S.C. $\S \S 3801-3807$ (2002) (expired Jun. 30, 2007).
} 
the U.S. Congress ${ }^{63}$ after more than a year of bickering over the appropriateness of including labor and environmental provisions in a trade agreement, occurred less than a month after the September 11, 2001 attack on the World Trade Center in New York. This was anything but coincidence. The JFTA, according to one report, was “intended to show U.S. appreciation of Jordan's efforts in supporting the Mideast peace process and in combating international terrorism ... The rush to pass the Jordan trade pact illustrates how the Sept. 11 attacks recalibrated, at least for a time, the politics of normally divisive issues such as trade." ${ }^{\prime 4}$ The Bush Administration also saw the JFTA as another means of advancing its anti-terrorism campaign. ${ }^{65}$

The post-Jordan U.S. FTAs with Morocco, Bahrain and Oman represented a key element in a broader U.S. political and economic strategy. That strategy was designed to encourage economic development and democracy in the Middle East and North Africa, with most of the same political/security considerations that were material in the conclusion of the JFTA. President Bush proposed in May 2003 the establishment of a United States-Middle East Free Trade Area within a decade, so as "to re-ignite economic growth and expanded opportunity in the Middle East." 9/11 Commission included a recommendation that "A comprehensive U.S. strategy to counter terrorism should include economic policies that encourage development, more open societies, and opportunities for people to improve the lives of their families and to enhance prospects for their children's future." ${ }^{97}$ The broader Middle Eastern FTA initiative faltered; negotiations with the United Arab Emirates were abandoned and discussions with Egypt were never initiated. ${ }^{68}$

However, the FTA negotiations with Morocco were completed. Bahrain and Oman were also well-qualified candidates, in part because both had acceded to the WTO, Bahrain as an original member in 1995, and Oman in 2000. ${ }^{69}$ The Morocco, Bahrain and Oman FTAs ${ }^{70}$ share far more similarities than differences with each other and with contemporary free trade agreements negotiated by the United States with developing countries in Latin America, particularly Chile and CAFTA-DR, discussed elsewhere in this or other chapters.

63 United States-Jordan Free Trade Area Implementation Act, Pl. 107-43, 107 $7^{\text {th }}$ Cong., $1^{\text {st }}$ sess., 115 Stat. 2431, 19 U.S.C. § 2112 Note (2001).

64 Warren Vieth \& Janet Hook, Senate Passes Free-Trade Pact with Key Ally Jordan, Los Angeles Times, Sep. 25, 2001, at A-8 [hereinafter "Vieth \& Hook"].

65 Id.

66 White House Fact Sheet, Proposed Middle East Initiatives, May 9, 2003, at 1, available at http://2001-2009.state.gov/p/nea/rls/20573.htm (last visited Mar. 26, 2016).

67 9/11 Commission Final Report, Jul. 22, 2004, at 378-379, available at http://www.911 commission.gov/report (last visited Mar. 26, 2016).

68 See Gary G. Yerkey, Some Progress Likely on $5^{\text {th }}$ Anniversary of Bush MEFTA Initiative; No New FTAs, 25 Int'L Trade Rep. (BNA) 102 (Jan. 17, 2008) (reporting that UAE discussions were suspended because of difficulties over investment, and deferred indefinitely with Egypt for political reasons).

69 Members and Observers, World Trade Organization, Nov. 30, 2015, available at https:// www.wto.org/english/thewto_e/whatis_e/tif_e/org6_e.htm (last visited Mar. 26, 2016).

$70 \quad$ See supra notes $34,38 \& 39$. 


\section{The Bush Era Free Trade Agreements in LATIN AMERICA AND AsIA}

As Rodrigo Monardes discusses in this issue, the U.S. FTA with Chile (and a simultaneous free trade agreement with Singapore) were the first fully comprehensive free trade agreements to follow NAFTA. The decision of the Clinton Administration in its last several months of office to propose formally the negotiation of these two agreements, knowing that they could not be seriously pursued until President Bush took office, undoubtedly reflected a final realization - if one were needed - that NAFTA was never going to be expanded, to Chile or any other country. It probably also reflected the inevitable conclusion that the Free Trade Agreement of the Americas, initiated by President Clinton in December 1994 at a Presidential summit in Miami, was doomed to fail. ${ }^{71}$

However, the Bush Administration, with USTR under the able, perhaps even visionary, leadership of Ambassador Robert Zoellick, almost immediately pursued the negotiations with Chile and Singapore, and concluded both negotiations in 2003. These were followed, in addition to the Middle Eastern agreements noted above, with an agreement with the five Central American nations and the Dominican Republic (CAFTA-DR). Shortly thereafter, free trade agreements with Colombia, Panama and Peru in Latin America (the "willing" after the end of the FTAA negotiations) were concluded. Korea, because of its growing economic might and less open markets, particularly toward foreign investment, offered potentially significant benefits to the United States and its stakeholders, and signed a free trade agreement with the United States in June 2007. Ultimately this comprised nine additional countries, all of which had had historically close (and in the case of the CAFTA-DR Parties, sometimes unpleasant) relations with the United States.

The CAFTA-DR, the U.S. FTA with the most significant developmental focus, is not discussed in detail because of its structural and substantive similarity with the Chile agreement and to a significant degree those concluded with Colombia, Korea, Panama and Peru all discussed by Jaemin Lee in this issue. CAFTA-DR was a decade ago considered equally or more important as a vehicle for economic development as it was for trade expansion per se. Such areas as rule of law, "trade capacity building," customs procedures, regulatory transparency, private property rights, competition, "civil society" participation, environmental protection, and labor law were all given priority coverage by the United States Government. ${ }^{72}$

The political path in Congress to the approval of these agreements was anything but straightforward. CAFTA-DR passed the House by only a few votes. Of the other four, concluded no later than 2007, only one, Peru, was approved by the end of the Bush Administration. The "Bipartisan Trade Deal" reached between the Bush White House and the Democratic Congressional leadership in May 2007 dictated some changes in the labor, environmental, intellectual property and a few other provisions. ${ }^{73}$ As a result the free trade agreement with Peru was enacted

See Kennedy, The Free Trade Agreement of the Americas, supra note 27.

See USTR, The Case for CAFTA, Feb. 2005, at 1, available at https:/ustr.gov/archive/assets/ Trade_Agreements/Regional/CAFTA/Briefing_Book/asset_upload_file235_7178.pdf.

73 Bipartisan Trade Deal, May 2007, available at https://ustr.gov/sites/default/files/ uploads/factsheets/2007/asset_upload_file127_11319.pdf. 
by Congress in November 2007, but the other three waited nearly four years for compromises to be worked out between the Obama Administration and a newly Republican House of Representatives in 2011 . $^{74}$

\section{The Trans-Pacific Partnership}

While the NAFTA has never been significantly modified or amended after more than 20 years, updating may finally be on the horizon indirectly through changes and other innovations in the TPP, many of which, as with investment, labor, environment and rules of origin, among others, would bring about major changes in NAFTA. That being said some $75 \%-80 \%$ of the content of NAFTA is found in most subsequent U.S. FTAs as well as in the TPP. Thus, for lawyers, academics and business persons who wish to understand and appreciate the TPP, one of the best ways to begin is to study the NAFTA, about which thousands of books and articles have been written on almost every aspect of the Agreement.

Thus, even though the TPP consists of 30 chapters rather than 22, much of what is found in NAFTA is also found in the post-Jordan U.S. agreements and the TPP. There is in fact a continuum of gradually increasing coverage of enforceable labor and environmental obligations (all part of the agreement itself) after NAFTA. Another major area of innovation is in changes to the ISDS provisions that represent a significant swing of the pendulum from broad investor protection to greater flexibility for governments in avoiding the risk of having to pay compensation as indirect expropriations or regulatory takings for non-discriminatory measures to protect public health or the environment. As well, the subsequent free trade agreements incorporate a variety of TRIPS-Plus expanded protections in certain areas of intellectual property, all discussed as noted earlier. The most significant new disciplines reflected in the TPP may be chapters dealing with ecommerce, state-owned enterprises, corruption and small and medium sized enterprises, but the SME chapter does not go much beyond creating a committee. ${ }^{75}$ While the scope of chapters on telecommunications, ecommerce, competition, capacity building, business facilitation, regulatory coherence and transparency has been somewhat expanded in TPP, similar provisions are found in recent U.S. FTAs such as those with Colombia, Korea, Panama and Peru.

The TPP, which was signed February 4, 2016, will probably not enter into force until sometime in 2018 at the earliest. Among other significant factors is the requirement that the agreement not enter into force under most likely scenarios unless and until at least six signatories, accounting for at least $85 \%$ of the combined GDP (thus including both the United States and Japan), have notified their acceptance of the agreement. ${ }^{76}$ The Trade Promotion Authority legislation, which will permit the TPP to be submitted to Congress for an up-or-down vote and without the possibility

\footnotetext{
74 See e.g., HR 3080 - United States-Korea Free Trade Agreement Implementation Act, P.L. 112-41, Oct. 21, 2011.

75 TPP, chs. 17, 24.

$76 \quad I d$. art. 30.5(2).
} 
of Amendment, was enacted in June 2015. ${ }^{77}$ However, in itself TPA does not assure that either President Obama or his successor (if she or he so desires) will be able to persuade a majority of both the Senate and House to support the TPP.

\section{Transatlantic Trade and Investment Partnership?}

The TTIP offers the significant attraction of further expanding an economic partnership that nearly fifty percent of the worlds' aggregate output, nearly $\$ 1$ trillion in annual bilateral trade (only modestly less than NAFTA) an estimated \$4 trillion in two-way investment and 13 million jobs, all according to the EU Commission. ${ }^{78}$ Should it be possible for the 28/27-member EU and the United States, with total combined population of over 800 million persons, to conclude this agreement, one could reasonably expect that the agreement could affect the content of future multilateral and plurilateral trade negotiations in Geneva, even if that impact is five or ten years away. This assertion assumes that the TTIP will address in unprecedented depth such areas as regulatory coordination and coherence, anticompetition, financial and other services, agricultural market access and investment, among others. For many definitions of success, the first two in particular should go beyond the scope of the treatment of those issues in the TPP or any other free trade agreement concluded by the European Union or the United States. Thus, as an EU Parliamentary study has asserted, the TTIP "has the potential to remake political and legal relationships between the European Union and the United States and pave the way to a new form of global economic governance based on international regulatory cooperation." 79

Unfortunately, meaningful assessment of the TTIP negotiations with any degree of confidence is impossible at present (October 2016). The negotiations are moving at a very slow pace. At the $12^{\text {th }}$ TTIP negotiating session held in Brussels in February 2016, various issues were discussed, including regulatory cooperation, standards, sanitary and phytosanitary measures, competition, customs and trade facilitation, state-to-state dispute settlement, small and medium sized enterprises, and the most controversial of all, investment protection. ${ }^{80}$ Given the higher priorities being devoted by the Obama Administration to securing enactment by the Congress of the TPP, the final TTIP negotiations will almost certainly be deferred at least

77 The Trade Adjustment Assistance (TAA) bill passed the House the second time as a separate bill by a vote of 286-138, with strong backing this time from the Democrats. House Approves TAA-Preferences Bill 286-138, with Strong Democratic Support, World TRAde Online, Jun. 25, 2015. (H.R. 1295 renews TAA for six years).

$78 \$ 3.7$ trillion in two-way investment according to Shayerah Ilias Akhtar \& Vivian C. Jones, Transatlantic Trade and Investment Partnership Negotiations, Cong. ResEARCH Service, Feb. 4, 2014, ii.

79 Alberto Alemanno, The Transatlantic Trade and Investment Partnership and Parliamentary Regulatory Cooperation, European Parliament, Apr. 2014, 5, available at http://papers.ssrn.com/sol3/papers.cfm?abstract_id=2423562.

80 See Statement by the EU Chief Negotiator Ignacio Garcia Bercero Following the Conclusion of the 12th TPP Negotiating Round, Feb. 29, 2016, available at http://trade. ec.europa.eu/doclib/docs/2016/february/tradoc_154325.pdf. 
until a new U.S. president has taken office in 2017. Moreover, U.S. Congressional leaders have accused the EU of a pattern of "hostage taking," in which European leaders "are expressing an inability and unwillingness" to complete the negotiations in 2016. Deficiencies in the EU negotiating positions asserted by congressional sources include an alleged unwillingness to fully eliminate tariffs; make enforceable commitments on digital trade; include an acceptable means of settling investment disputes; and strengthen commitments on sanitary and phytosanitary issues. ${ }^{81}$ Thus, the question remains whether the European Union and the United States have the mutual political will to conclude an agreement that effectively addresses the key issues or will ultimately settle for some sort of "TTIP Lite."

81 Rosella Brevetti, Congressional Leaders Charge EU with 'Hostage Taking” in Trade Talks, 33 Int'L Trade Reporter (BBNA) 1425 (Oct. 6, 2016). 
